\title{
Correction to: Confabulating as Unreliable Imagining: In Defence of the Simulationist Account of Unsuccessful Remembering
}

\author{
Kourken Michaelian ${ }^{1}$ (D)
}

Published online: 27 December 2018

(c) The Author(s) 2018

\section{Correction to: Topoi \\ https://doi.org/10.1007/s11245-018-9591-z}

The article "Confabulating as Unreliable Imagining: In Defence of the Simulationist Account of Unsuccessful Remembering", written by "Kourken Michaelian", was originally published electronically on the publisher's internet portal https://link.springer.com/article/10.1007/s11245-0189591-z on 15 October 2018 without open access.

With the author(s)' decision to opt for Open Choice the copyright of the article changed on 26 December 2018 to $($ ) The Author(s) 2018 and the article is forthwith distributed under the terms of the Creative Commons Attribution 4.0 International License (http://creativecommons.org/licenses/ by/4.0/), which permits use, duplication, adaptation, distribution and reproduction in any medium or format, as long as you give appropriate credit to the original author(s) and the source, provide a link to the Creative Commons license and indicate if changes were made.

The original article has been corrected.

Open Access This article is distributed under the terms of the Creative Commons Attribution 4.0 International License (http://creativeco mmons.org/licenses/by/4.0/), which permits unrestricted use, distribution, and reproduction in any medium, provided you give appropriate credit to the original author(s) and the source, provide a link to the Creative Commons license, and indicate if changes were made.
The original article can be found online at https://doi.org/10.1007/ s11245-018-9591-z.

Kourken Michaelian

michaelian.kourken@gmail.com

1 Laboratoire PPL, Université Grenoble-Alpes, Bat. ARSH,

CS 40700, 38058 Grenoble Cedex, France 